\title{
The Perpetual Quest for Author(ity) and Authenticity in Flaubert's Parrot
}

Flaubert'in Papağanı Romanında Yazar, Otorite ve Özgünlük Arayışı

\author{
F. Zeynep Bilge \\ Mimar Sinan Fine Arts University, Turkey
}

\begin{abstract}
Julian Barnes's Flaubert's Parrot (1984) is significant in its employment of metafiction, which is one of the key characteristics of the postmodern novel. Flaubert's Parrot can be defined as a self-reflexive text, which is utterly aware that it is fiction. Moreover, it presents an intertextual network, which connects Gustave Flaubert's Un coeur simple and Madame Bovary with the fictional amateur biographer Geoffrey Braithwaite's narrative. The narrator/protagonist Braithwaite's quest for truth and certainty, ironically, creates a multi-layered narrative involving multiple points of view. The novel's portrayal of (the lack of) truth, knowledge, and certainty becomes more conspicuous with the twenty-first century's emphasis on post-truth. The novel questions the relationship between real life and fiction, and the parrot becomes the embodiment of this mutual relationship. Furthermore, it can be argued that the imitative nature of the parrot emphasizes the relationship between life and art as well. With this semi-biographical novel Barnes not only fictionalizes Flaubert but also poses existential questions to critics and scholars. The speculations concerning an author's life and the creativity of the biographer accentuate the lack of) boundaries between fact and fiction, life and art, author and critic. That is the reason why the primary aim of this paper is to display this novel's relation to postmodernism as well as the nature of the collaboration and/or the battle between the author and the biographer/critic/academic.
\end{abstract}

Keywords: Julian Barnes, Flaubert's Parrot, postmodern novel, metafiction, authenticity

Öz

Julian Barnes'ın Flaubert'in Papağanı (1984) romanı postmodern roman türünün temel özelliklerinden biri olan üst kurmacadan yararlanması açısından önemlidir. Bu romanı, kurmaca yapısının bilincinde olan öz-düşünümsel bir metin olarak tanımlamak mümkündür. Ayrıca, Gustave Flaubert'in Saf Bir Yürek öyküsü ve Madam Bovary romanları ile amatör biyografi yazarı olan Geoffrey Braithwaite karakterinin anlatısını birleștirerek metinlerarası bir ağı da gözler önüne serer. Romanın ana karakteri ve anlatıcısı olan Braithwaite'in doğruluk ve kesinlik arayışı ironik bir biçimde farklı bakış açılarının sunulduğu çok katmanlı bir anlatının ortaya çıkmasına neden olur. Romanın gerçek, bilgi ve kesinlik gibi kavramların varlığını (ya da yokluğunu) yansıtma biçimi yirmibirinci yüzyıl dünyasının hakikat sonrası kavramına yaptığı vurguyla daha da çarpıcı bir hal alır. Roman, gerçek yaşamla kurmaca ilişkisini sorgular; papağan ise bu karşılıklı ilişkinin vücut bulmuş hali olur. Bununla beraber, papağanın taklitçi doğasının sanatla yaşam arasındaki ilişkiyi temsil ettiğini iddia etmek de mümkündür. Bu yarı-biyografik romanında Barnes yalnızca Flaubert'i

CUJHSS, June 2021; 15/1: 37-49.

(C) Çankaya University ISSN 1309-6761 Printed in Ankara

Submitted: June 30, 2020; Accepted: April 21, 2021

ORCID\#: 0000-0002-6217-8280; zeynep.bilge@msgsu.edu.tr 
kurmaca dünyanın parçası yapmakla kalmaz, aynı zamanda eleștirmen ve akademisyenlere de varoluşsal sorular yöneltir. Bir yazarın yaşamına ilişkin tahminler ve biyografi yazarının yaratıcılığı gerçek ile kurmaca, yaşam ile sanat ve yazar ile eleştirmen arasındaki sınır(sızlığ)ı vurgular. Bu nedenle, bu çalışmanın temel amacı romanın postmodernizmle ilișkisini ve yazar ile biyografi yazarı/eleştirmen/akademisyen arasındaki iş birliğinin ve/veya çatışmanın doğasını gözler önüne sermektir.

Anahtar Kelimeler: Julian Barnes, Flaubert'in Papağanı, postmodern roman, üst kurmaca, gerçeklik

"What happened to the truth is not recorded" Flaubert's Parrot

Flaubert's Parrot, which was first published in 1984, challenges concepts such as genre, truth, history, and meaning. In parallel with the fact that many have already found it difficult to categorise the text as a novel, Julian Barnes himself defines Flaubert's Parrot as an "upside down, informal piece of novelbiography" (Barnes, "Julian Barnes in Conversation" 259). Flaubert's Parrot is one of the most profound examples of the postmodern novel, which deconstructs the genre with its emphasis on intertextuality, fragmentation, and metafiction. The novel predominantly displays an apparent intertextual relationship with Madame Bovary and Un coeur Simple [A Simple Heart]. It bends the norms and conventions of the novel genre by embracing various forms of writing, including chronology, dictionary, and even examination paper. Being an example of metafiction, Flaubert's Parrot consistently emphasises that it is fiction. The novel's narrator/protagonist Geoffrey Braithwaite not only directly addresses the reader but also refers to the previous pages of the novel while communicating with the reader: "Do you know the colour of Flaubert's eyes? No, you don't: for the simple reason that I suppressed it a few pages ago. I didn't want you to be tempted by cheap conclusions" (95). With this approach, the novel takes itself out of the conventions of the genre, questions its own identity, and sets fresh rules to be challenged. Accordingly, this study aims at presenting a discussion on concepts such as author, authority, and authenticity in postmodern literature with a close reading of Barnes's work. The novel employs the conventions of postmodernism in literature such as fragmentation, disorientation, and relativism, which display multiple truths, multiple identities, and multiple views of reality. Flaubert's Parrot, which is first published almost four decades ago, becomes even more remarkable in an age that is defined with the term post-truth. ${ }^{1}$

The book is narrated by Geoffrey Braithwaite, who "thought of writing books [him]self once" (13). Defining himself as an amateur Flaubert scholar, Braithwaite takes the reader on a journey, while attempting to determine the

1 "Post-truth" is first used in the 1990s, and since the 2010s it functions as a concept defining the current political mood as well as the human condition worldwide. Hence, the contemporary reader's perception of this early example of postmodern literature is in accordance with the lack of truth and certainty that is experienced in the twenty-first century. 
whereabouts of the original stuffed parrot which inspired Flaubert's short story Un coeur simple. Like almost all journeys, this is essentially a soul journey, in which Braithwaite tries to reconcile with his past. In other words, the search for the stuffed parrot as well as the historical "facts" 2 concerning Flaubert are intermingled with the autobiographical details of the narrator. Hence, Braithwaite's research is utterly engaged with the combination of the so-called facts and fiction by its nature.

The narrator's approach towards his subject matter -both the stuffed parrot and Flaubert- and the contents of the novel look familiar to the literary scholar, in reminding them of the preparation process of an academic work. Taking notes, making lists, writing down chronological details, focusing on certain words and terms, consciously or subconsciously associating the subject matter with personal experiences, and even thinking about potential examination questions while discussing the subject matter are not alien to the academic. Hence, analysing this novel allows the scholars to examine their own academic identities as well as their relation to their studies because by their nature, academic work and "biographies offer models of how others live, face challenges, and cope with change; they are prime sites for studying ourselves" (Benton, "Literary Biography" 44).

Both biography writing and research in literature are "conceived in a process of interpreting the evidence" (Schabert 3). In this argument, the word "interpretation" is substantial because it emphasizes the direct relationship between the subject matter and the biographer/critic/academic. The relationship between the author, the literary text, and the reader becomes even more challenging when the author becomes the subject of a biography. Flaubert's Parrot, with its postmodern approach, displays power relation between the three. Once the authority figure as the author of literary works, Gustave Flaubert becomes the subject of another text.

Both the author and the literary scholar, including the amateur ones like Braithwaite, reveal their existence through language and their writings. Pen -or the keyboard in the (post)modern age- and words function as the ultimate tool for communication. The idea of communication through writing is further emphasized in relation to Braithwaite's unsatisfied desire to become an author. He admits that he once thought of writing books himself: "I had the ideas; I even made notes. But I was a doctor, married with children. You can only do one thing well: Flaubert knew that. Being a doctor was what I did well. My wife ... died. My children are scattered now; they write whenever guilt impels" (13). This statement is a declaration of Braithwaite's perception of success, failure 3 ,

\footnotetext{
2 The concept of historical facts is challenged with the presence of three alternating chronologies concerning Flaubert's life. As it is discussed in the following pages of this study, different chronologies create alternating truths and facts, which display relativism and multiple points of view.

3 It is also worth mentioning that the reader has no proof to believe that this unreliable narrator is a successful doctor. Moreover, his reference to his late wife's death right after declaring that he was a good doctor is ironic in itself.
} 
family, loneliness and authorship. Furthermore, thinking about his failed attempts to write reminds him of his past and family; and most importantly at this point in the novel, Braithwaite is not yet ready to talk about his past particularly about his relationship with his late wife. Hence, the blank (...) after the reference to his wife is going to be filled towards the end of his narrative, when his search for the original stuffed parrot is over.

Braithwaite's communication with his reader is also indicative of the postmodern attitude Barnes employs in this novel. The narrator/protagonist functions as a bridge between the reader of Barnes's novel and Flaubert (both as a person and an author of literary works). In other words, the fictional narrator becomes a portal between history and fiction. As Daniel Bedggood argues, "the placing of the narrator within the schematic consideration of historical 'proof' also alerts the reader to the postmodern referential presence of metafiction, the self-conscious acknowledgement or emphasis of the text as a literary object" (212). While the novel objectifies its own genre, history and fiction are interconnected as a crucial indicator of metafiction.

In his discussion on how the narrator/protagonist establishes a personal relationship with the reader by directly addressing them in various instances, Péter Tamás argues that Braithwaite "gradually constructs an audience of his own in an effort to establish his writerly authority" (90). Tamás's argument supports the idea that authority and authorial identity are significant themes that are examined throughout the novel. In Braithwaite's comments on Flaubert, the reader is allowed to observe and interpret Braithwaite's so-called authority on his subject matter, language, and life. Certain chapters of the novel, especially the "Examination Paper," which contains exam questions focusing on a wide variety of disciplines, underlines Braithwaite's claim that he is not only "an authority on Flaubert" (94) but he is also an expert in numerous fields such as literary criticism, economics, logic, geography, and history. ${ }^{4}$ With Braithwaite's thirst for authority is ironic with respect to postmodern literature's relation to concepts such as authority and mastery. As Linda Hutcheon emphasizes, in postmodernism "we find masterful denials of mastery, totalizing negations of totalization" (Hutcheon, "History and/as Intertext" 169). Despite Braithwaite's attempts to prove the opposite, Barnes's novel distorts all possibility of mastery and totalization in accordance with postmodern theory.

The title of the novel, as well as Braithwaite's "self-appointed quest" (Martin 6), focuses on Flaubert's parrot rather than Flaubert the man or the author. The parrot, which is a reference to Loulou in Flaubert's short story Un coeur simple, is symbolic in both texts. In Un coeur simple when it is still alive, the parrot functions as the ultimate companion for the main character Félicité. However, when it is dead and stuffed, it is transformed in metaphoric terms as well: As

\footnotetext{
4 Throughout the novel Braithwaite is presented as the narrator and the protagonist, which indicates that he is the one who also prepares the questions in Chapter 14 entitled "Examination Paper". The licence to set an exam focusing on numerous fields is in accordance with his claim of authority.
} 
the story concludes, Félicité associates Loulou with the Holy Spirit. In Barnes's novel-biography, however, the parrot is ironically associated with authenticity, truth and history5. Furthermore, according to Braithwaite, the stuffed parrot is "the emblem of the writer's voice" (19). On the one hand, depicting an animal, which is associated with mimicry and repetition, as a symbol of authenticity is puzzling. This association becomes even more problematic in the end of the novel, when it is understood that there are many stuffed parrots that may have been the source of inspiration for Flaubert's Loulou. As Andrzej Gasiorek argues, "there is no single truth anymore than there is a single parrot" (158), which takes us back to the postmodern nature of Barnes's text. While challenging the traditionally accepted form of the genre, this postmodern novel celebrates fragmentation and multiplicity through its "refusal of totalisation" (Guignery 41). On the other hand, the parrot's connection with mimicry and imitation is reminiscent of the continuous debates on the relationship between art and life: Does art imitate life? Or does life imitate art? Regardless of the answer to this question (which is beyond the limits and the focus of this study), the correlation between this particular relationship and the image of the parrot is remarkable with respect to the concept of imitation.

Like many other works of Barnes, this novel is concerned with authenticity, truth, memory, history and reliability. In Barnes's own words,

it's a book about the shiftingness of the past, and the uncertainty and unverifiability of fact, [...] and it's a book, and it's a novel about Flaubert, and so on, and it's a novel about love: how the love of art compares with love of a human being - and I think perhaps beyond all that it's a novel about grief, it's a novel about a man whose inability to express his grief and his love is shifted. ("Julian Barnes in Conversation" 262)

The shiftingness of the past is exquisitely exemplified in Chapter 2, which is entitled "Chronology". In this chapter, the reader is presented three alternating versions of chronology focusing on Flaubert's life. The first chronology starts with Flaubert's birth and mostly focuses on the publication of his important works as well as the dates he meets with the important figures in his life, such as Louise Colet. The second chronology, on the other hand, starts with the deaths of Flaubert's siblings before his birth, suggesting that this chronology does not designate the author's birth as the starting point of his life. This approach argues that an individual's life is also shaped with the events prior to their birth and highlights the continuity of life. Moreover, the second chronology includes more comments, when compared to the first version. Another apparent characteristic of the second chronology is its emphasis on death, pain, decay, and suffering. The third chronology, however, is written in first person, and looks more like a diary. Instead of Flaubert's birth year or the years in which his elder siblings pass away, the third version begins in 1842, when Flaubert is already twenty years old. Due to its structure, which is

\footnotetext{
5 It is of no coincidence that, instead of the full portrayal of a parrot, the covers of various editions of the novel present feathers reminding the reader of quill pens.
} 
reminiscent of a diary, this version focuses on personal thoughts and emotions rather than historical facts. In order to fully display the differences between these three chronologies, analysing the final entries of each would be appropriate:

I

1880 Full of honour, widely loved, and still working hard to the end, Gustave Flaubert dies at Croisset (27). [...]

II

1880 Impoverished, lonely and exhausted, Gustave Flaubert dies. Zola, in his obituary notice, comments that he was unknown to fourfifths of Rouen, and detested by the other fifth. He leaves Bouvard et Pécuchet unfinished. Some say the labour of the novel killed him; Turgenev told him before he started that it would be better as a short story. After the funeral a group of mourners, including the poets François Coppée and Théodore de Banville, have dinner in Rouen to honour the departed writer. They discover, on sitting down the table, that they are thirteen. The superstitious Banville insists that another guest be found, and Gautier's son-in-law Emile Bergerat is sent to scour the streets. After several rebuffs he returns with a private on leave. The soldier has never heard of Flaubert, but is longing to meet Coppée (31). [...]

III

1880 When will the book be finished? That's the question. If it is to appear next winter, I haven't a minute to lose between now and then. But there are moments when I'm so tired that I feel I'm liquefying like an old Camembert. (37)

Accordingly, the fundamental distinction between these three chronologies lies in the approaches they employ towards their subject matter. Although all three chronologies end with Flaubert's death in 1880, the way the last entry focuses on death varies in each version. The third chronology, which is written in first person, and hence fully underlines its subjective approach, correlates weariness with death. It is an autobiographical chronology, written by the fictionalised Gustave Flaubert, who is not aware of the fact that he is going to die soon. Therefore, the reader who knows the fact that the real Flaubert dies in 1880 , reads this entry with that pre-knowledge.

However, the first chronology, while focusing more on facts, presents Flaubert as a loved and honourable individual. The second chronology, on the contrary, depicts the author as a detested man. The contradictory portrayal of the same individual is indicative of the subjective nature of biography writing. Like all kinds of writing - including novels, diaries, letters, and autobiographies biographies too employ a subjective reading of the subject matter. As Philip Holden argues, "What Barnes plays with, then, is both the non-identity of career author and historical figure, and the investment of the biographer as reader writing his own individualized biography" (928). In this way, postmodernism's intricate relationship with biography is also revealed in this 
novel. As Katherine Frank suggests, "biographical characters from a postmodernist perspective are linguistic constructs, untethered to the past and what really happened" (9). Hence the acclaimed French author Flaubert is transformed into a linguistic construct in Braithwaite's narrative.

These alternating chronologies - in other words, historicised accounts of Flaubert's life - display the subjective structure of history. Hutcheon, while referring to Frederick Jameson and Hayden White in her analysis of the interaction between history and fiction, argues that "History as narrative account, then, is unavoidably figurative, allegorical, fictive; it is always already textualized, always already interpreted" (Hutcheon, "History and/as Intertext" 170). Barnes, in his postmodern work, evidently proves the textualized and interpreted nature of history. Presenting the life of a real author in three utterly distinct ways is indicative of the role of the historian, who introduces subjectivity into history writing. Although Braithwaite does not define himself as a historian, his narrative and particularly the chapter entitled "Chronology" displays the subjective, and even fictive aspect of history writing. Once again, point of view, which is one of the crucial focal points emphasized by postmodern literature, becomes dominant in Barnes's argument that is displayed in the given chapter.

Scepticism towards the word and language is one of the highlighted postmodern aspects of this novel-biography. The arbitrary nature of language, and the lack of a natural relationship between the word and the referent (or the signifier and the signified in linguistic terms) is displayed through multiple points of view (end even multiple chronologies). Thus, the text questions and challenges the concept of truth. The novel also provokes scepticism towards all individuals within the text, such as the narrator/protagonist, Flaubert, and Dr Enid Starkie. This distrust is further accentuated in Braithwaite's definition of the past as "autobiographical fiction pretending to be a parliamentary report" (90). Braithwaite's perception of the past is later echoed in The Sense of an Ending by Adrian: "history is that certainty produced at the point where the imperfections of memory meet the inadequacies of documentation" (17). ${ }^{6}$ In the second half of Flaubert's Parrot, starting with the "Cross Channel" chapter, "Braithwaite is much more interested in the 'unspoken' or 'potential' elements of Flaubert than the known or familiar" (Hateley 180)7. Apart from the introduction of fiction into the lives of real people while writing their biographies, biographers, as Richard Holmes suggests,

base their work on sources which are inherently unreliable. Memory itself is fallible; memories are inevitably biased; letters are always slanted towards their recipients; even private diaries and intimate

\footnotetext{
${ }^{6}$ Barnes's The Sense of an Ending (2011) focuses on past, memory, truth, and subjectivity in a similar way. Both Flaubert's Parrot and The Sense of an Ending underline the subjective approaches employed in remembering and interpreting past events

7 One should also note that Flaubert's Parrot even has a chapter on Flaubert's unwritten works, entitled "The Flaubert Apocrypha". This chapter presents a fundamental question about unwritten literature: "Do the books that writers don't write matter?" (115).
} 
journals have to be recognized as literary forms of self-invention rather than an 'ultimate' truth of private fact or feeling. The biographer has always had to construct or orchestrate a factual pattern out of materials that already have a fictional or reinvented element. (17)

Similar to Holmes's definition of biography writing as a pursuit and a haunting, Michael Benton suggests that during this process "the biographer turns from pursuer to pursued" (Benton, "Reading Biography" 77). Therefore, the reader of Barnes's novel learns the life story of Braithwaite rather than that of Flaubert. Hence, Amia Lieblich's argument is exemplified through Braithwaite's portrayal as a biographer in Barnes's text: "biography will always be autobiographical as well. It must be self-reflective, and since it is based on a relationship, the biographer cannot avoid being there with her feelings, her fears, hopes and satisfactions, and her own echoes of the tales of the protagonist's life" (209).

Braithwaite, who is attempting to work on Flaubert's biography, seems to interconnect his work in progress with his own autobiography. Therefore, the main focus of this novel-biography as well as the predominant authority figure is not definite throughout the text. The affinity between the words "author," "authority" and "authenticity" becomes a substantial part of the relationship between Flaubert, Braithwaite, Barnes, and the reader. "Author" and "authority," which are both derived from the Latin "auctor" meaning master and inventor, are utterly interrelated with respect to their meaning: The authors are traditionally claimed to have so-called authority over their texts for creating them. As stated earlier, this attitude towards the concept of authority (which is also reflected in Braithwaite's longing for being regarded as an authority figure) is challenged in postmodern literature.

Although the term authenticity is not derived from the same Latin root, it is significant that there is a correlation between the meanings of these three words, besides the similarity between their pronunciation: The word "authentic" comes from the Greek "authentikos" -which means "principal, genuine" - and "authentes" - which means "lord, master". "The historical genealogy of the term reveals authenticity as a highly volatile and historically contingent concept comprising three frames of utility: classical truth to an ideal, artistic truth to self, and positive definitions of collective identity" (Claviez, et. al. viii). Authenticity in this study is rather related to the concept of genuineness since the question of authenticity is a significant aspect of the novel from the beginning with the first reference to Flaubert's statue in Rouen: "This statue isn't the original one. The Germans took the first Flaubert away in 1941, along with the railings and door-knockers. Perhaps he was processed into cap-badges" (11). The fact that this particular statue is not the original one obviously foreshadows the question of authenticity that is primarily related to the stuffed parrot. What is most conspicuous in this quotation is that Braithwaite talks about the statue as if it is Flaubert himself. He even uses the personal pronoun "he" for the statue, while arguing that it may have been "processed into cap-badges". This personification evidently, and ironically, 
turns the real author into an inanimate object and the statue into a human being. The immortality of the public figures, including writers and artists of all kinds, is largely two-sided. Although their works and legacy are immortalised, they can be turned into statues or become a part of the commercial daily life: "Along the avenue Gustave Flaubert, past the Imprimerie Flaubert and a snackbar called Le Flaubert: you certainly feel you're going in the right direction" (15). These names suggest that naming various symbols of the commercialist system after the nineteenth-century author, inevitably turns him into a commodity. It would not be farfetched to suggest that reconstructing the image of Gustave Flaubert by naming certain places after him is similar to recreating the parrot through taxidermy. On the one hand, in Flaubert's Un coeur simple the parrot is immortalised on a physical level, but it is turned into an inanimate object that is designed to be exhibited. Keeping the skin of this parrot in a frozen posture obviously indicates the amount of loneliness Félicite is experiencing. Yet, taxidermy cannot offer an eternal solution to Félicité's loneliness. Towards the end of her life, she not only loses her sight but also has to part with the stuffed parrot since its reconstructed body is falling apart.

As mentioned before, the narrator/protagonist of this novel defines himself as an amateur Flaubert scholar. Through this literary biography, the reader observes how the author(ity) of literary texts becomes the subject matter of another text. As Alison Lee suggests, in this novel "[m]ade-up characters are treated as though they were real, and, conversely, real people are rendered fictional" (46). Apart from the portrayal of Flaubert throughout the novel, Louise Colet's fictional narrative is one of the palpable examples of how real people are fictionalised. This is an indication that the novelist or even the biographer "may invent episodes which elucidate the historical personality as he conceives it" (Schabert 6). Furthermore, Chapter 11, which is entitled "Louise Colet's version," emphasises the multiple points of view presented within this postmodern text. The reader is given the opportunity to read the events related to Flaubert through the perception of a different character. Another real human being who becomes a part of this fictional biography is Enid Starkie (1897-1970), an esteemed Irish literary critic, who particularly specialized on French literature and wrote on Flaubert. While referring to Dr Starkie and her arguments on Flaubert ${ }^{8}$, Braithwaite comments on Starkie - as the representative of professional critics and scholars in general - as well: "I can't prove that lay readers enjoy books more than professional critics; but I can tell you one advantage we have over them. We can forget. Dr Starkie and her kind are cursed with memory: the books they teach and write about can never fade from their brains" (75). Once again, the novel focuses on the intricate relationship between reading, past, and memory. Braithwaite, who has the courage to conduct a research on Flaubert, places himself with lay readers opposite to the professional critics and scholars.

8 It is also significant to note that "Barnes's quotations from her criticism are accurate" (Holden 929). 
Throughout the novel, Braithwaite is associated with two types of quests: "the simple [quest] is the attempt to locate and authenticate a stuffed parrot. The enactment of this quest facilitates the complex quest, one of psychological individuation and acceptance" (Hateley 177). In other words, while searching for Flaubert's literary voice symbolized by the stuffed parrot, what Braithwaite truly aims at achieving is coming to terms with his wife Ellen's infidelity and suicide. Hence, the intertextual bond between Madame Bovary and Flaubert's Parrot is implicated with Charles Bovary and Braithwaite's occupation, as well as their wives's extramarital affairs. While focusing on Flaubert on the surface, Braithwaite admits his real motivation: "Books are not life, however much we might prefer it if they were. Ellen's is a true story; perhaps it is even the reason why I am telling you Flaubert's story instead" (86). Although Braithwaite argues that there is an evident distinction between life/reality and fiction, the totality of the book claims the opposite.

Chapter 13, which is entitled "Pure Story," primarily focuses on Braithwaite's late wife Ellen. This is the chapter in which the reader learns the details of their relationship, including Ellen's adultery and Braithwaite's reaction to her death. Therefore, the emphasis on the word "pure" is utterly intriguing. According to Vanessa Guignery,

the ontological status of this fictional but 'pure' story is ambiguous, as underscored by the polysemy of 'pure'. Does 'pure story' mean 'not corrupted', as opposed to Emma Bovary's corrupted one; 'purely imaginary' as opposed to all the chapters relating to real people and places; or 'true story', as understood by French translator Jean Guiloineau, who entitled the chapter 'Une histoire vraie [A true story]'? (42)

In Braithwaite's terms, the "pure story" refers to how he perceives his wife's death. When he talks about how he decides to switch off the machines keeping her alive at the hospital, in other words how he kills her, Braithwaite says that "she wasn't corrupted. Hers is a pure story. I switched her off" (168). Since the reader continuously has to remind themselves not to fully trust narrators, or even their own memories, it can be suggested that the ambiguity concerning the emphasis on the word "pure" prevails even after Braithwaite's statement. Furthermore, this section in his narrative is notable since there is an obvious change in the sentence structure. Braithwaite's sentences are much shorter suggesting anxiety and uneasiness; and this uneasiness threatens his authority over his own narrative.

In "Pure Story," which is placed towards the end of the novel, Braithwaite starts to come to terms with his past. He gradually begins to talk about his past, which is understood to be the reason why he finds himself on this quest:

Ellen. My wife: someone I feel I understand less well than a foreign writer dead for a hundred years [...] Books are where things are explained to you; life is where things aren't [...] Books make sense of 
life. The only problem is that the lives they make sense of are other people's lives, never your own. (168)

"Pure Story" also functions as a confession, in which Braithwaite frankly admits the real reason behind his quest. Hence, this narrative can be regarded as Braithwaite's attempt to make sense of his own life - as opposed to what he claims in the above stated extract. While discussing the concept of confession in Tolstoy, Rousseau, and Dostoevsky's writings with respect to Augustine's perception of the term, J. M. Coetzee argues that

confession is one element in a sequence of transgression, confession, penitence and absolution. Absolution means the end of the episode, the closing of the chapter, liberation from the oppression of the memory. Absolution in this sense is therefore the indispensable goal of all confession, sacramental or secular. (194)

When Braithwaite manages to talk about Ellen's infidelity, her suicide, and his role in her death, he is ready for a secular absolution, which prepares the ending of the novel. This confession reveals his character to a great extent; the text displays the personality, the identity of the narrator/protagonist rather than Flaubert's, who is presented as the so-called subject of the narrative.

Flaubert's Parrot is a novel about identity: the identity of the stuffed parrot, the identity of Flaubert, the identity of Braithwaite, the identity of Ellen, and the identity of the reader. When the reader recalls that Julian Barnes, as an author, has repeatedly challenged the idea of a single voice and a sole identity through the various pen names he employs while publishing his works, his stance against the idea of a single truth is appreciated in the broadest sense. The author of Flaubert's Parrot is known as Julian Barnes, Dan Kavanagh, Edward Pygge, and others at the same time. Barnes has written crime fiction under the pseudonym Dan Kavanagh - a name which is derived from his late wife Pat Kavanagh. Apart from this pseudonym, Barnes has also employed different pen names, while particularly writing for newspapers and periodicals:

The Edward Pygge name was a tradition of the Review and the New Review, so he was actually a pseudonym that I inherited. And it was an honor not granted to many people to be Edward Pygge. And you had to write in a certain style to be Edward Pygge. In this certain acerbic and un-illusioned style about literary matters. Basil Seal I used because I was a restaurant critic and you didn't want them to know who you were. [...]

The other pseudonyms, which are more trivial, or less often used, were simply because of my output at the time. If I was writing the New Statesman television column, I couldn't have another piece in the same issue under the same name. So if I was doing fiction roundup or something like that, I simply used a pseudonym. I quite liked using one, there was something liberating about it. (Barnes, Conversations with Julian Barnes 175-176) 
What Barnes highlights in this comment is the liberating aspect of writing under various pseudonyms. While liberating the author to remain anonymous to a certain extent, the use of pseudonyms provokes a question of identity and authenticity. So, would it be farfetched to suggest that an analysis of the use of pseudonyms, which challenges the relationship between authorial identity and authenticity, is not different from Braithwaite's search for the original stuffed parrot? After all, they are all related to a sense of truth about identity.

Ironically, the quest for the stuffed parrot, which provides the novel with its name, is fully discussed in the final chapter "And the Parrot..." Presenting himself as a kind of a detective, Braithwaite in this chapter comments on the death of the author. In the final sentence of his narrative, he has to accept and acknowledge that there are too many stuffed parrots. In Hutcheon's words,

postmodern novels like Flaubert's Parrot, Famous Last Words, and $A$ Maggot openly assert that there are only truths in the plural, and never one Truth; and there is rarely falseness per se, just others' truths. Fiction and history are narratives distinguished by their frames. $(A$ Poetics of Postmodernism 109)

The postmodern novel, which challenges concepts such as totalisation, authenticity, and truth, sets new rules for itself. Julian Barnes's Flaubert's Parrot, in this respect, uses the image of the stuffed parrot in constructing a multi-layered postmodern view on literature. The quest for the original stuffed parrot functions as a symbol for the narrator/protagonist's exploration of his own past; and hence the narrative, as well as Braithwaite's quest, ends only two chapters after he declares why and how his late wife dies. Similar to the fact that there are multiple "original" stuffed parrots that may have influenced Flaubert in creating Loulou, there are multiple roles that are attributed to the stuffed parrot in Braithwaite's narrative. As a reminder of Gustave Flaubert's life as an individual and an author, it reminds the reader of the quill pen. With its plural existence, the stuffed parrot demonstrates that there is no single truth in postmodern world. As such, the quest for authority and authenticity proves to be in vain. Braithwaite's quest for authenticity and certainty, ironically, creates a multi-layered narrative involving multiple points of view. What is more, at the end of the narrative both Braithwaite and the reader acknowledge that there is no such thing as authenticity.

The final chapter opens with an Holmesian declaration: "And the parrot? Well, it took me almost two years to solve the Case of the Stuffed Parrot" (180). Yet, the solution of the case lacks certainty: "perhaps [the original stuffed parrot] was one of them" (190, my emphasis). The emphasis on the concept of probability and multiplicity in this sentence reflects the postmodern characteristic of the novel. Moreover, since Braithwaite verbalizes the assumption that the original stuffed parrot may be one of the Amazonian parrots he sees at the Museum of Natural History, Braithwaite finally seems to embrace uncertainty, multiplicity, fragmentation, and lack of authenticity. The search for the original stuffed parrot, which, as far as Braithwaite is concerned, symbolizes the real Flaubert, results in the acceptation of multiple truths and 
identities. While celebrating fragmentation and disorientation, Barnes's postmodern novel proposes questions concerning concepts such as verification, relativism, and narrative, which play a significant role in defining our current age of post-truth.

\section{Works Cited}

Barnes, Julian. Conversations with Julian Barnes. Edited by Vanessa Guignery and Ryan Roberts. University Press of Mississippi, 2009.

---. Flaubert's Parrot. Vintage, 1990.

---. "Julian Barnes in Conversation." Cercles 4, 2002, pp. 255-269.

---. The Sense of an Ending. Alfred A. Knopf, 2011.

Bedggood, Daniel. "(Re)Constituted Pasts: Postmodern Historicism in the Novels of Graham Swift and Julian Barnes." The Contemporary British Novel Since 1980. Edited by James Acheson and Sarah C. E. Ross. Palgrave Macmillan, 2005, pp. 203-216.

Benton, Michael. "Literary Biography: The Cinderella Story of Literary Studies." The Journal of Aesthetic Education, Vo. 39, No. 3, Autumn, 2005, pp. 44-57.

---. "Reading Biography." The Journal of Aesthetic Education, 41.3, 2007, pp. 77-88.

Claviez, Thomas, Kornelia Imesch, Britta Sweers. Critique of Authenticity. Vernon Press, 2020.

Coetzee, J. M. "Confession and Double Thoughts: Tolstoy, Rousseau, Dostoevsky." Comparative Literature, Summer, Vol. 37, No. 3, 1985, pp. 193-232.

Frank, Katherine. "Experiments with Truth: Writing Biography Today." India International Centre Quarterly, Vo. 24, No. 4, Winter 1997, pp. 1-12.

Gasiorek, Andrzej. Post-War British Fiction: Realism and After. Edward Arnold, 1995.

Guignery, Vanessa. The Fiction of Julian Barnes (Readers' Guides to Essential Criticism). Kindle Edition, Palgrave Macmillan, 2006.

Hateley, Erica. "Flaubert's Parrot as modernist quest." $Q / W / E / R / T / Y$ : Arts, Literatures \& Civilisations du Monde Anglophone, 11, 2001, pp. 177-181.

Holden, Philip. "Literary Biography as a Critical Form." Biography, fall 2014, Vol. 37, No.4., pp. 917-934.

Holmes, Richard. "Inventing the Truth." The Art of Literary Biography. Ed. John Batchelor. Clarendon Press, 1995.

Hutcheon, Linda. A Poetics of Postmodernism: History, Theory, Fiction. Routledge, 1988.

---. "History and/as Intertext." Ed. John Moss. Future Indicative: Literary Theory and Canadian Literature. University of Ottawa Press, 1987, pp. 169-184.

Lee, Alison. Realism and Power: Postmodern British Fiction. Routledge, 1990.

Lieblich, Amia. "Writing Biography as a Relationship." Nashim: A Journal of Jewish Women's Studies \& Gender Issues, No. 7, Autobiography and Memoir, Spring 5764/2004, pp. 206-211.

Martin, James. Inventing Towards Truth: Theories of History and the Novels of Julian Barnes. University of Arkansas, 2001, MA Dissertation.

Schabert, Ina. "Fictional Biography, Factual Biography, and their Contaminations." Biography Vol. 5, No. 1, Winter 1992, pp. 1-16.

Tamás, Péter. "If I were a Dictator of Fiction' Readerly and Writerly Anxiety of Influence in Julian Barnes's Flaubert's Parrot." Stunned into Uncertainty: Essays on Julian Barnes's Fiction. Edited by Eszter Tory \& Janina Vesztergom. Eötvös Loránd University, 2014, pp. 85-96. 